\title{
Review
}

\section{Exercise-Induced Modulation of Neuroinflammation in Models of Alzheimer's Disease}

\author{
Áine M. Kelly* \\ Department of Physiology, School of Medicine \& Trinity College Institute of Neuroscience \& Trinity \\ Biomedical Sciences Institute, Trinity College Dublin, University of Dublin, Dublin, Ireland
}

Accepted: 11 July 2018

Published: 11 December 2018

\begin{abstract}
Alzheimer's disease (AD), a progressive, neurodegenerative condition characterised by accumulation of toxic Beta-amyloid $(A \beta)$ plaques, is one of the leading causes of dementia globally. The cognitive impairment that is a hallmark of $\mathrm{AD}$ may be caused by inflammation in the brain triggered and maintained by the presence of $\mathrm{A} \beta$ protein, ultimately leading to neuronal dysfunction and loss. Since there is a significant inflammatory component to AD, it is postulated that anti-inflammatory strategies may be of prophylactic or therapeutic benefit in AD. One such strategy is that of regular physical activity, which has been shown in epidemiological studies to be protective against various forms of dementia including AD. Exercise induces an anti-inflammatory environment in peripheral organs and also increases expression of anti-inflammatory molecules within the brain. Here we review the evidence, mainly from animal models of AD, supporting the hypothesis that exercise can reduce or slow the cellular and cognitive impairments associated with AD by modulating neuroinflammation.
\end{abstract}

Keywords: Exercise, microglia, astrocytes, neuroinflammation, Alzheimer's disease

\section{INTRODUCTION}

The prevalence of sporadic Alzheimer's Disease $(\mathrm{AD})$, the most common form of dementia, is increasing in proportion with life expectancy [1]. As yet, there is no effective treatment of $\mathrm{AD}$; the cholinesterase inhibitors and N-MethylD-aspartate (NMDA) glutamate receptor antagonist drugs presently prescribed can only slow the worsening of symptoms of the disease [2], while efforts to develop effective and safe therapies targeted at

\footnotetext{
*Correspondence to: Áine M. Kelly, Department of Physiology, School of Medicine \& Trinity College Institute of Neuroscience \& Trinity Biomedical Sciences Institute, Trinity College Dublin, University of Dublin, Dublin 2, Ireland. E-mail: aikelly@tcd.ie.
}

clearing the amyloid $\beta(A \beta)$ plaques that characterize AD have failed [3]. Discovery of effective treatments for $\mathrm{AD}$ will likely require a fuller understanding of the pathogenesis and progression of the disease than we now possess. While the question of how the disease is triggered remains unanswered, a collection of modifiable and non-modifiable risk factors for $\mathrm{AD}$ have been identified, including age, genetic factors, dietary factors, metabolic disease and cardiovascular disease [4]. Encouragingly, a number of modifiable lifestyle factors that may mitigate risk of development of AD have also been identified; these include diet [5], education and mental activity [6, 7] and social engagement [8]. However the most potent of these lifestyle factors appears to be exercise $[9,10]$, which will be the focus of this review. 
An acute neuroinflammatory response can be initiated by factors including infection, ischemia, and trauma that cause the activation of microglia. These 'resident macrophages of the brain' (Box 1) produce and secrete cytokines such as interleukin-1 (IL-1), interlekin-6 (IL-6), and tumour necrosis factor $\alpha$ (TNF- $\alpha)$, which can lead to recruitment of peripheral immune cells to the brain and elimination of infection-causing pathogens or repair of damage from an imposed trauma [11]. Astrocytes, the most numerous cell type in the brain, contribute to acute immune responses such as adjusting the permeability of the blood brain barrier (BBB) to allow immunologically active molecules into the central nervous system (CNS) from the periphery [12] and secretion of cytokines [13] (Box 1). However a chronic neuroinflammatory response is associated with a number of neurodegenerative diseases, including AD [14]. Although initially this inflammation was considered to be solely detrimental, more recently it has been proposed that inflammation has the potential to contribute positively to brain repair, including the regeneration and clearance of pathological aggregates [15]. As such, strategies to modify inflammation within the brain may be of preventive or therapeutic benefit in the context of AD.

One such strategy may be engagement in regular physical activity. Sedentary behavior has been associated with impaired cognitive function in old age [16, 17], while regular exercise appears to preserve cognitive function in later life $[18,19]$. Although physical activity is inversely linked with risk of development of $\mathrm{AD}[9,20,21]$, the type, frequency, intensity and duration of exercise required to reduce risk has not as yet been identified [22]. The mechanisms underlying this exercise-induced protection may include preservation of brain volume [23] and the patency of the cerebral vasculature [24], with evidence from animal studies strongly linking exercise and maintenance of cognitive function with neurogenesis and expression

Box 1

Roles of glia in neuroinflammation

Microglia are considered the resident immune cell of the brain. Under resting conditions, they exist primarily in a state of surveillance in the CNS and their major role is the maintenance of homeostasis within the brain microenvironment [157]. Maintenance of microglia in a relatively quiescent state is attributed in part to astrocyte and neuronal activity [158]; for example, neurons can facilitate microglial quiescence by secreting signal factors including CD200, CX3CL1 and neurotrophins $[159,160]$. Microglia share phenotypic characteristics with peripheral monocytes cells and, during injury to the CNS, are polarized towards a pro-inflammatory phenotype (M1 state), induced mainly by exposure to pro-inflammatory cytokines, such as IFN- $\gamma, \mathrm{TNF}-\alpha$ and cellular or microbial debris. The M1 state is characterised by production of pro-inflammatory cytokines, including TNF- $\alpha$, IL- $1 \beta$ and IL- 6 and increased expression of inducible nitric oxide synthase (iNOS), inducing elevated production of NO and morphological change of microglia to an amoeboid shape [161]. However, in an effort at neuroprotection and repair, microglia can assume an 'alternative' activation, featured by an anti-inflammatory phenotype (M2 state). The M2 activation can be driven by anti-inflammatory cytokines, such as IL-4, IL-13 and IL-10 [162] and is characterised by increased production of anti-inflammatory cytokines, including IL-4, IL-10, IL-13, as well as upregulation of Arginase-1 (Arg1), Chitinase-3-like-3 (Ym1, in rodents) and Mannose receptor C (MRC-1) [163, 164]. Microglia activated towards the M2 state can also trigger inflammation resolution through the release of other anti-inflammatory factors, such as neurotrophins (eg BDNF) and growth factors (IGF-1 and transforming growth factor beta -TGF- $\beta$ ) $[165,166]$. An involvement of microglial activation has been identified in the pathophysiology of several neurodegenerative diseases, such as AD and Parkinson's Disease (PD), mainly by increasing neurotoxicity and cellular damage, thereby contributing to the degenerative process $[167,168]$. While polarisation toward an M1 or M2 state can be readily induced in vitro, the complex nature of the brain microenvironment and the multiple signals that glia are exposed to makes it likely that a spectrum of intermediate transitional activation states exists in vivo $[169,170]$. Nevertheless, manipulation of microglial polarization is being actively investigated as a potential therapeutic strategy in a number of neurodegenerative conditions [171].

Astrocytes are the most populous cells in the CNS, where they provide structural and functional support to neurons, form part of the blood brain barrier (BBB) and participate in synaptic formation [172]. While their main role is in neuronal support and brain homeostasis [173], it is accepted that they play an important role in neuroinflammation [174]. Similar to microglia, astrocytes can be activated from the resting state in response to insults and pathologies and this reactive astrogliosis is characterised by increased expression of GFAP [175]. Activated astrocytes have been shown to be a significant source of pro-inflammatory cytokines, including TNF- $\alpha$, IL-1 $1 \beta$ and IL-6 as well as other inflammatory mediators such as iNOS [176, 177]. Most recently, a harmful/helpful A1/A2 classification, analogous to the microglial M1/M2 phenotypes, has been suggested though it is proposed that, again similar to microglia, a continuum of activation states is likely, especially in vivo [178]. Accordingly, astrocytes exposed to IL-4 and IL-10 show typical "alternative" activation (A2 phenotype), increasing expression of Arg-1, Mrc-1 and Ym1 [176], while activated astrocytes can also help in tissue repair by releasing IL-10, which has been reported to supress neuronal apoptosis through TLR/NF- $\kappa$ B pathway activation [179]. In addition, astrocyte reactivity has been associated with several neurodegenerative diseases, including Huntingtons Disease, PD and AD [180-182] and most recently, it was suggested that the normal process of ageing induces astrocytes to present A1-like astrocyte reactivity, with pro-inflammatory features [183].

The ability of reactive astrocytes and microglia to influence each other's morphology and function is now being painstakingly investigated, for example it has recently been shown that the A1-type astrocyte phenotype can be induced by neuroinflammatory microglia [184]. It is hoped that investigation of the cross-talk between microglia, astrocytes and neurons will yield insights that may inform therapeutic interventions in diseases and disorders of the brain, including AD. 
of brain-derived neurotrophic factor (BDNF) [25]. These data fit with the proposed theory of 'cognitive reserve' [26, 27], whereby lifestyle factors render individuals more resilient to insult, injury, age-related neurodegeneration or, with respect to $\mathrm{AD}$, to the functional consequences of amyloid pathology [28].

More recently, the anti-inflammatory properties of physical activity have been increasingly investigated. Abundant research demonstrates the overall anti-inflammatory effects that exercise induces in peripheral body organs, and that these effects may contribute to the decreased risk of development of cardiovascular and metabolic disorders [29]. Increasing evidence indicates that these anti-inflammatory effects extend to the brain, reducing risk of development of neurodegenerative disorders that exhibit a significant inflammatory component, including $\mathrm{AD}$ $[30,31]$.

\section{AD AND MODELS OF AD}

The Bavarian psychiatrist and neuropathologist Alois Alzheimer first described the pathology of the disease that bears his name more than 100 years ago when he associated memory loss in a female patient with senile plaques identified in her brain postmortem [32]. Memory loss is, of course, the major clinical symptom of $\mathrm{AD}$ [33] and the disease progression can be staged clinically according to the degree of cognitive impairment from normal age forgetfulness through mild cognitive impairment to mild, moderate and severe AD [34]. The classic pathological lesions that are a hallmark of $\mathrm{AD}$ are characterized by extracellular plaques, composed mainly of amyloid $\beta(A \beta)$, and intracellular neurofibrillary tangles (NFTs) consisting of hyperphosphorylated tau protein, and progression of the disease results in neuronal loss and consequent brain shrinkage [35]. The severity of AD correlates more closely with the distribution of NFTs than the amyloid plaques [36-38] and activated astrocytes and microglia are found at the lesion sites, indicating an inflammatory component to the pathology $[39,40]$. The generation of the neurotoxic amyloid species that constitute AD plaques by proteolysis of the amyloid precursor protein (APP) is well-described and has been extensively reviewed eg $[41,42]$. Very briefly, the amyloidogenic pathway of APP processing involves cleavages at specific sites by $\beta$ - and $\gamma$-secretases that generate $A \beta$ fragments that can oligomerize and fibrillize, leading to $\mathrm{AD}$ pathology. While the presence of plaque pathology is diagnostic of $\mathrm{AD}$, advances in imaging technology have revealed that a cohort of the aged population have a high amyloid burden but no cognitive impairment [43], and that evidence of plaque pathology can precede symptoms of $\mathrm{AD}$ by as much as 20 years [44]. This is strong evidence to indicate that factors other than amyloid plaques, including NFTs and neuroinflammation, contribute to the loss of memory and other cognitive functions typical of AD.

Attempts to mimic in rodents the pathology of $\mathrm{AD}$ seen in the post-mortem human brain have been informed mainly by identification of the amyloid composition of $\mathrm{AD}$ plaques and by genetic information garnered from patients with familial Alzheimer's Disease (FAD), now commonly referred to as Early Onset Alzheimer's Disease (EOAD). EOAD, which usually becomes symptomatic in patients under the age of 65 , is a rapidly progressing form of the disease and accounts for only 5-10\% of all AD cases [45]. Mutations in three genes encoding APP, and the $\gamma$-secretase complex subunits presenilin 1 (PS1) and presenilin 2 (PS2), are causal in EOAD and are considered diagnostic [4], although these gene mutations account for only a small number of families with EOAD, indicating that additional AD-causing genes remain to be identified [45]. The sporadic form of $\mathrm{AD}$, although influenced by environmental factors, is also impacted by genetics, the major gene investigated thus far being the $\varepsilon 4$ allele of the apolipoprotein gene (APOE) [46-48]. However, genome-wide association studies are strongly suggesting a causative role for inflammation or immune dysfunction in $\mathrm{AD}$ $[48,49]$.

No transgenic mouse model can replicate pathology in the human brain precisely, but overexpression of mutated forms of APP, PS1 and/or Tau in the mouse brain has provided a means by which to assess the development and functional consequences of $\mathrm{AD}$ like pathology [50-52]. While over 100 genetically engineered mouse lines have been developed with this goal in mind, there is a small number that has been widely used and in which pathology and cognition is well characterized [53] and will be focussed on here. With respect to APP, the Tg2576 model that overexpresses the 'Swedish' mutation [54] and the PDAPP that overexpresses the 'Indiana' mutation [55] show progressive AP deposition, loss of synapses, apoptosis, gliosis and hyperphosphorylated Tau, but no NFTs $[50,56]$. Mutation of PS1 results in increased neurotoxic $A \beta$, but this mouse shows no plaque pathology [57]. Double and triple mutations have been employed in an attempt to model AD 
pathology more closely. For example the APP/PS-1 mouse shows an early and accelerated AP deposition with evidence of astrocytosis around $\mathrm{A} \beta$ deposits and loss of dendritic spines [50, 58, 59]. As with the APP point mutation models, there is no development of NFTs but hyperphosphorylation of Tau $[60,61]$ and neuronal loss [62] have been observed. The $3 \times \mathrm{Tg}$, triple transgenic mouse model overexpresses mutated Tau in addition to APP and PS1; in these mice, hyperphosphorylation of tau and NFTs develop in middle-age, following development of plaque pathology, and astrocytosis is also present [63-65]. It is worth noting that, given the lack of NFTs in the majority of these models, it has been suggested that at least some represent models of amyloidosis rather than $\mathrm{AD}$ per se. It is also worth noting that evidence of inflammation is seen consistently in the region of plaques and lesions, which reflects the human pathology. Finally, not all approaches to modeling AD have been genetic; the disease has also been widely mimicked by direct infusion of aggregated amyloid into the brain ventricles [66, 67] or parenchyma [68], though these in general model acute responses to brief exposures to $A \beta$, in contrast to the chronic $A \beta$ exposure characteristic of the disease process.

Cognitive deficits and impaired synaptic plasticity are consistently, and sometimes simultaneously, observed in mouse models of $\mathrm{AD}$, as has been reviewed several times [52, 69], however these impairments do not always correlate temporally with AD-like pathology [50]. A $\beta$ deposits are seen in PDAPP and Tg2576 from 6 months with deficits in spatial learning appearing prior to the pathology and increasing in severity with age in the case of PDAPP [70]; in $\operatorname{Tg} 2576$ mice the memory deficits reflect the timing of amyloid deposition more closely, but some learning impairments are noted prior to observation of significant pathology [71, 72]. Deficits in spatial working memory as assessed using the Ymaze appear in the APP/PS1 mouse as early as 3 months [73], at around the time amyloid deposition first appears, while deficits in the water maze task, and recognition memory appear from 6 and 12 months respectively $[74,75]$. Memory deficits in the $3 \times T g$ mice as measured by Morris water maze and inhibitory avoidance tasks appear at 3 months [76, 77], coinciding with onset of $A \beta$ deposition, with progressive impairment in a range of cognitive functions apparent from 6 months onward [78].

The characterization of these models behaviourally and pathologically has allowed spatiotemporal links between amyloid pathology and cognitive function to be assessed and has revealed that these markers of AD do not necessarily correlate. However, consistent evidence of robust neuroinflammatory responses within the brain has been observed in each model, which has allowed this characteristic aspect of $\mathrm{AD}$ pathology to be explored.

\section{AD AND NEUROINFLAMMATION}

Neuroinflammation is a major feature of $\mathrm{AD}$ neuropathology, as has been recently and comprehensively reviewed [79-83]. There is evidence of increased proinflammatory cytokine expression in the $\mathrm{AD}$ brain $[84,85]$, which may increase the risk of progression from mild cognitive impairment to more severe stages of $\mathrm{AD}$ [86]. The presumed source of these cytokines is the reactive astrocytes and microglia that have been observed in the postmortem AD brain $[39,40]$. Furthermore, genome-wide association studies have suggested that genes associated with increased risk of inflammatory disease also increase risk of $\mathrm{AD}$ [87]. Accordingly, there is some evidence that long-term use of non-steroidal antiinflammatory drugs (NSAIDs) may reduce risk of $\mathrm{AD}$, although randomized control trials in the clinic have yet to prove successful [88].

These findings in the human brain have prompted assessments of the neuroinflammatory contribution to cognitive impairment and AD-like pathology observed in animal models. These studies, both in vivo and in vitro, have shown that $\mathrm{A} \beta$ can bind to pattern recognition receptors in both astrocytes and microglia, inducing an innate immune response [89]. With respect to astrocytes, AD-associated neuroinflammation is accompanied by reactive astrogliosis, the morphological and functional change seen in astrocytes in response to CNS injury or damage [90]. This has been repeatedly demonstrated in the APP/PS1 mouse [91, 92]. During this process, astrocytes are activated and undergo hypertrophy and/or proliferation [93] that can be identified by increased expression of glial fibrillary acidic protein (GFAP) [94], an intermediate filament protein of the astrocytic cytoskeleton. Reactive astrocytes are intimately associated with amyloid plaques in $\mathrm{AD}[95]$ and they can detect, take up and degrade $A \beta$, possibly via its high affinity for the nicotinic acetylcholine receptors expressed on astrocytes [39]. Astrocytes can become overburdened with $A \beta$, leading to their dysfunction and consequent lysis, contributing to formation of the amyloid plaque [96]. The debate as to whether 
astrocytes are neuroprotective or detrimental in AD is still ongoing, and likely may depend on the phenotype of the activated astrocytes in the plaque region (Box 1). Similarly, the question of whether inflammatory changes mediated by astrocytes, and indeed microglia, contribute to pathogenesis of the disease or if they are secondary to deposition of amyloid- $\beta$ or other pathological changes remains unanswered. While astrogliosis contributes to AD pathology by upregulating the expression of pro inflammatory cytokines and chemokines and regulating the generation and degradation of $A \beta$, the presence of $A \beta$ has been shown to disrupt gliotransmission, neurotransmitter uptake, and alter calcium signaling in astrocytes, events that are linked with the cognitive dysfunction characteristic of AD [97]. Conversely, deletion of the genes encoding the filament proteins GFAP and Vimentin, that are required for astrocyte activation, in the APP/PS1 mouse model resulted in rapidly progressing neuropathology due to an increased plaque load and more abundant dystrophic neurites, furthering the hypothesis that astrocytes play a neuroprotective role within the CNS [98].

When microglial cells become activated they phagocytose target particles, release cytokines and, in some cases, free radicals [99]. In the case of neurodegenerative disorders, including AD, microglia can fail to carry out their normal functions, such as clearance of pathological protein aggregates and cell debris. They become chronically activated, continuously releasing neurotoxic substances, contributing to the pathogenesis of $\mathrm{AD}$ [100]. Activation of microglia can result in two opposing effects; beneficial antiinflammatory effects leading to the clearance of $A \beta$ and the release of neurotrophic factors or detrimental effects caused by the release of pro-inflammatory cytokines and free radicals [99]. In mouse models such as APP/PS-1, activated microglia accumulate in the vicinity of $A \beta$ plaques [101]; upregulation of microglial markers has been reported in these mice as early as three months [102] and persists at 14 months and 24 months [103]. Unsurprisingly, microglial upregulation is coincident with expression of proinflammatory cytokines including IL- $1 \beta$ and TNF $\alpha$ [103, 104]. The use of in vivo multiphoton microscopy has demonstrated that when plaques begin to form in APP/PS-1 mice, microglial cells begin to aggregate around them within one to two days and that this aggregation is followed by dysmorphic changes in neurites [105]. Microglial activity can be modified by cytokine stimulation in these mice. Treating APP/PS-1 mice with macrophage colony- stimulating factor (M-CSF) leads to an increase in the number of microglia, their phagocytic activity towards $A \beta$ and a consequent reduction in the number of $A \beta$ plaques and improvement in cognitive function [106]. Treatment with the anti-inflammatory cytokine IL-4 in another model of AD, the Tg2576 mouse, reduced astrocytosis and microgliosis and decreased amyloid plaque number and load, changes that were accompanied by improvements in working memory [107]. However, experimental attenuation of neuroinflammation and impaired synaptic function in $\mathrm{AD}$ mouse models, in this case APP/PS-1 knock-in mice, is not always associated with alterations in amyloid pathology [108]. Finally, it has been proposed that microglia contribute to the progression of $\mathrm{AD}$ pathology via their senescence within the aged brain. The neuroprotective and phagocytic capabilities of these cells therefore reduce, rendering them less effective at combatting repeated insults in the aged or diseased brain and allowing pathology to worsen progressively [109].

A substantial volume of data demonstrates the significant contribution of inflammatory processes to $\mathrm{AD}$ pathology and the cognitive impairment associated with it. The search for appropriate drug targets and development of effective pharmaceuticals continues, with anti-inflammatory strategies likely to hold promise as prophylactics or therapeutics. However lifestyle interventions, especially exercise, can also generate anti-inflammatory stimuli that may prove effective in the prevention and treatment of AD.

\section{EXERCISE AND INFLAMMATION}

Accumulating evidence strongly supports a general anti-inflammatory role of exercise [110], though the molecular mechanisms have not yet been fully elucidated. In part, this anti-inflammatory effect seems to be related to the direct action of exercise on immune adaptations that occur locally in the exercised skeletal muscle. Skeletal muscle produces and secretes several cytokines, termed myokines, which mediate many of the metabolic changes induced by exercise [111]. The best known myokine is IL-6, which is released from working muscle during exercise and whose increase is reported to upregulate systemic production of anti-inflammatory cytokines, mainly IL-10, and to downregulate systemic levels of pro-inflammatory cytokines, such as TNF- $\alpha$ and IL-1 $\beta[112,113]$, suggesting that IL- 6 produced by skeletal muscle is a primarily anti-inflammatory 
effector. Regular exercise modulates the peripheral immune system, decreasing circulating inflammatory cytokines e.g. TNF- $\alpha$, and IL- $1 \beta$ and increasing anti-inflammatory cytokines such as interleukin (IL)10 [114]. Exercise can transform adipose resident macrophages from a pro-inflammatory (M1) state, to an anti-inflammatory (M2) state via a mechanism believed to involve the downregulation of toll-like receptor (TLR)-4 expression on several cell types including adipocytes, monocytes, and hepatocytes, leading to a substantial reduction in inflammation and an associated decrease in the risk of development of many non-communicable diseases [29, 115].

Exercise may also exert powerful antiinflammatory effects in the brain. In animal studies, exercise upregulates IL-10 expression and attenuates the increase in pro-inflammatory cytokine expression in the brain associated with age [116], and lipopolysaccharide (LPS)-induced inflammation [117]. In addition, exercise has been shown to prime microglia and astrocyte activation by decreasing the number of ionized calcium binding adaptor molecule 1 (Iba-1) $^{+}$and $\mathrm{GFAP}^{+}$cells in hippocampus and cortex, in parallel with an enhancement in spatial memory [118], while it has also been shown to increase the number of microglial cells co-localized with BDNF and to protect against cognitive decline in aged mice [117]. Together, these data suggest that exercise-induced enhancement or protection of cognitive function might be associated with the modulatory effect of exercise on systemic and central inflammatory profiles.

Of course, the beneficial effects of exercise on the structure and function of the brain may be mediated by mechanisms other than modulation of inflammation; in particular, a link between exercise, adult hippocampal neurogenesis and preservation of cognitive function in old age has been researched extensively. However the importance, or even presence, of neurogenesis in the adult human brain is hotly debated. As outlined in a recent minireview [119], widely-cited reports of adult human neurogenesis as assessed by bromodeoxyuridine (BrdU) labeling [120] and radiocarbon dating [121] have recently been both supported [122] and contradicted [123] thus we are far from reaching a consensus on this point. Regardless of the outcome of this debate, it is clear that the rodent brain is very neurogenic throughout the lifespan $[124,125]$ and many investigations of the functional consequences of neuroinflammation, the AD-type phenotype and the effect of exercise on both, have assessed neurogenesis as an output.
Accordingly, experimentally-induced neuroinflammation that activates microglia impairs neurogenesis in a manner that can be reversed by microglial inhibition [126] or administration of NSAIDs [127]. Similarly, IL-1 $\beta$ has been shown to directly reduce neurogenesis [128-130].

\section{EXERCISE, NEUROINFLAMMATION AND AD}

The ability of short- or long-term exercise to induce changes in brain structure and function has been assessed in a variety of mouse models of $\mathrm{AD}$, using either voluntary (wheel running) or forced (treadmill running) exercise paradigms. The use of different models and exercise regimes at different ages makes it difficult to directly compare study outcomes. Nevertheless, in general, exercise has been seen to improve cognitive function in $\mathrm{AD}$ models, in a manner that in some studies is coincident with decreased A $\beta$ load, increased neurogenesis or decreased inflammation (Table 1). While studies in the APP/PS1 [131-134], Tg2576 [135, 136], Tg-NSE/hPS-2 [137, 138], 3xTg $[138,139]$ and $\mathrm{Tg} 4-42$ [140] models have shown a beneficial effect of exercise on AD pathology and cognitive function, here we place emphasis on the few studies to date that have assessed the impact of exercise on neuroinflammation.

The majority of such studies have used the APP/PS1 model and usually the exercise protocols commence after the age at which plaques have begun to form. For example, a ten week intervention of voluntary wheel running begun in five month old mice, ie when plaque formation has begun but is not yet well advanced, led to a reduction in the number of $\mathrm{GFAP}^{+}$astrocytes in the hippocampus [141]. This was coincident with improved spatial learning in the water maze, increased hippocampal neurogenesis and decreased numbers of $A \beta$ plaques and cells positive for phosphorylated tau when compared with sedentary controls. Similar results were observed in a group of APP/PS1 mice that also began exercise at five months, but with a regime of five months treadmill running [142]. Although cognitive function was not assessed, $A \beta$ plaque number and size were reduced as were the number of $\mathrm{GFAP}^{+}$cells, but not Iba- $1^{+}$cells, indicating modulation of astrocyte but not microglial activation. Exercise begun later in life has also yielded positive results. A fiveweek treadmill running protocol begun at the age of 7 months or 24 months old attenuated the activa- 
Table 1

Exercise-induced effects on inflammation in mouse models of $\mathrm{AD}$

\begin{tabular}{|c|c|c|c|c|c|}
\hline Reference & Age & Exercise & AD pathology & Cognitive function & Inflammation \\
\hline \multicolumn{6}{|c|}{$\mathrm{APP}_{\mathrm{SWE}} / \mathrm{PS}-1 \triangle \mathrm{E9}-\mathrm{A} \beta$ plaques develop from 3-6 months [185] } \\
\hline $\begin{array}{l}\text { Zhang et al., } \\
\text { (2018) [142] }\end{array}$ & 5 months & $\begin{array}{l}5 \text { months treadmill } \\
\text { running }\end{array}$ & $\begin{array}{l}\downarrow \mathrm{A} \beta \text { and plaque } \\
\text { number and size }\end{array}$ & & $\begin{array}{l}\downarrow \mathrm{GFAP}^{+} \text {cells } \\
\text { No reduction in } \\
\text { Iba- } 1^{+} \text {cells }\end{array}$ \\
\hline $\begin{array}{l}\text { Tapia-Rojas et al., } \\
\text { (2015) [141] }\end{array}$ & 5 months & $\begin{array}{l}\text { Ten weeks voluntary } \\
\text { wheel running }\end{array}$ & $\begin{array}{l}\downarrow \mathrm{A} \beta \text { oligomers and } \\
\text { plaque deposits } \\
\downarrow \text { p-Tau }^{+} \text {cells }\end{array}$ & $\begin{array}{l}\text { Improved } \\
\text { performance in MWM }\end{array}$ & $\downarrow \mathrm{GFAP}^{+}$cells \\
\hline $\begin{array}{l}\text { Xu et al., (2013) } \\
\text { [144] }\end{array}$ & 10 month & $\begin{array}{l}\text { Six weeks wheel } \\
\text { running, two hours } \\
\text { per day }\end{array}$ & $\begin{array}{l}\text { No effect on } \beta \& \gamma \\
\text { secretase expression } \\
\text { and } A \beta 42 \text { protein } \\
\text { levels }\end{array}$ & $\leftrightarrow \mathrm{MWM}$ & $\begin{array}{l}\text { No reduction in } \\
\text { GFAP }^{+} \text {and Iba- } 1^{+} \\
\text {cells }\end{array}$ \\
\hline $\begin{array}{l}\text { Ke et al., (2011) } \\
{[143]}\end{array}$ & $\begin{array}{l}7-8 \& 24 \\
\text { month }\end{array}$ & $\begin{array}{l}\text { Five week treadmill } \\
\text { running protocol }\end{array}$ & $\begin{array}{l}\downarrow \mathrm{A} \beta 42 \text { expression in } \\
\text { adult mice } \\
\leftrightarrow \mathrm{A} \beta \text { plaque number } \\
\text { in aged mice }\end{array}$ & $\begin{array}{l}\leftrightarrow \text { passive avoidance } \\
\text { Improved } \\
\text { performance in MWM } \\
\text { in aged, not adult mice }\end{array}$ & $\begin{array}{l}\downarrow \text { Microglial } \\
\text { activation in adult and } \\
\text { aged mice }\end{array}$ \\
\hline \multicolumn{6}{|c|}{ Tg2576 - A $\beta$ plaques develop from 9-12 months [54] } \\
\hline $\begin{array}{l}\text { Nichol et al., } \\
(2008) \text { [146] }\end{array}$ & 16-18 months & $\begin{array}{l}\text { Three weeks } \\
\text { voluntary wheel } \\
\text { running }\end{array}$ & $\downarrow$ soluble $\mathrm{A} \beta$ & & $\begin{array}{l}\downarrow \mathrm{IL}-1 \beta \text { and TNF } \alpha \\
\uparrow \mathrm{CD} 40 \text { and MHCII }\end{array}$ \\
\hline $\begin{array}{l}\text { Parachikova et al., } \\
\text { (2008) [147] }\end{array}$ & 15-19 months & $\begin{array}{l}\text { Three weeks } \\
\text { voluntary wheel } \\
\text { running }\end{array}$ & $\begin{array}{l}\text { No effect on amyloid } \\
\text { pathology }\end{array}$ & $\begin{array}{l}\text { Improved } \\
\text { performance in radial } \\
\text { arm water maze }\end{array}$ & $\begin{array}{l}\uparrow \text { IL-11, CXCL1 \& } \\
\text { CXCL12 mRNA }\end{array}$ \\
\hline \multicolumn{6}{|c|}{ Tg-NSE/hPS-2 - A $\beta$ plaques develop from 12 months old [186] } \\
\hline $\begin{array}{l}\text { Koo et al., (2013) } \\
{[149]}\end{array}$ & 24 months & $\begin{array}{l}\text { Three month treadmill } \\
\text { running protocol }\end{array}$ & & $\begin{array}{l}\text { Improved } \\
\text { performance in MWM }\end{array}$ & $\begin{array}{l}\downarrow \mathrm{COX} 2 \text { protein } \\
\downarrow \text { Caspase-3 protein }\end{array}$ \\
\hline $\begin{array}{l}\text { Um et al., (2011) } \\
{[150]}\end{array}$ & 24 months & $\begin{array}{l}\text { Three month treadmill } \\
\text { running protocol }\end{array}$ & $\begin{array}{l}\downarrow \text { Hippocampal A } \beta 42 \\
\text { protein } \\
\downarrow \text { Tau } \\
\text { phosphorylation }\end{array}$ & $\begin{array}{l}\text { Improved } \\
\text { performance in MWM }\end{array}$ & $\begin{array}{l}\downarrow \mathrm{COX} 2 \text { protein } \\
\downarrow \text { Caspase-3 protein }\end{array}$ \\
\hline $\begin{array}{l}\text { Leem et al., } \\
\text { (2011) [148] }\end{array}$ & 16 months & $\begin{array}{l}\text { Three month treadmill } \\
\text { running protocol }\end{array}$ & $\begin{array}{l}\downarrow \text { Tau } \\
\text { phosphorylation }\end{array}$ & & $\begin{array}{l}\downarrow \mathrm{GFAP}^{+} \text {cells } \\
\downarrow \text { MAC- } 1^{+} \text {cells } \\
\downarrow \text { TNF- } \alpha \text { IL-1 } 1 \beta \text { and } \\
\text { IL-6 mRNA } \\
\downarrow \text { COX-2 iNOS }\end{array}$ \\
\hline \multicolumn{6}{|c|}{ Triple transgenic mice - A $\beta$ plaques develop from 3-4 months [63] } \\
\hline $\begin{array}{l}\text { Do et al., (2018) } \\
\text { [154] }\end{array}$ & 8 weeks & $\begin{array}{l}\text { Four weeks voluntary } \\
\text { wheel running }\end{array}$ & $\begin{array}{l}\text { No pathology in } \\
\text { hypothalamus }\end{array}$ & & $\begin{array}{l}\downarrow \text { TNF-a and IL-6 in } \\
\text { hypothalamus }\end{array}$ \\
\hline $\begin{array}{l}\text { Haskins et al., } \\
\text { (2016) [187] }\end{array}$ & 3 months & $\begin{array}{l}12 \text { weeks treadmill } \\
\text { running }\end{array}$ & & & $\begin{array}{l}\uparrow \text { RANTES in blood } \\
\downarrow \text { RANTES in cortex } \\
\downarrow \text { MCP-1 in }\end{array}$ \\
\hline \multicolumn{6}{|c|}{ THY-Tau22 - p-Tau ${ }^{+}$cells develop from three months old [188] } \\
\hline $\begin{array}{l}\text { Belarbi et al., } \\
\text { (2011) [151] }\end{array}$ & 3 months & $\begin{array}{l}\text { Nine months } \\
\text { voluntary wheel } \\
\text { running }\end{array}$ & $\begin{array}{l}\downarrow \text { Abnormal p-Tau } \\
\text { expression }\end{array}$ & $\begin{array}{l}\text { Improvement in } \\
\text { spontaneous } \\
\text { alternation }\end{array}$ & $\begin{array}{l}\text { No effect on GFAP } \\
\text { cells and IL-1 } 1 \beta \text {, } \\
\text { TNF- } \alpha \text { and CD } 68 \\
\text { mRNA in the } \\
\text { hippocampus }\end{array}$ \\
\hline
\end{tabular}

tion of microglia [143], although neither astrocyte number nor activation was assessed in this study. Performance of the older mice in the Morris water maze was improved, but no change in the $\mathrm{A} \beta$ plaque number was observed. Conversely, other studies have shown no effect of exercise on glial activation. Six weeks of wheel running begun at 10 months of age yielded no observable change in numbers of GFAP ${ }^{+}$ astrocytes and Iba- $1^{+}$microglia, nor any effect on $\mathrm{A} \beta 42$ protein expression or spatial learning [144], 
though in this study exercise was combined with antioxidant treatment. Mixed results have also been observed in other AD models. In the Tg2576 model, three weeks of wheel running begun at 16-18 months, which has been shown to improve performance in the radial arm water maze [145] decreases soluble $A \beta$ and reduces IL- $1 \beta$ and TNF $\alpha$ in the hippocampus to wild-type levels. In parallel, it increases expression of Cluster of differentiation 40 (CD40) and major histocompatibility complex class II (MHCII), found on antigen-presenting cells, in the hippocampus, indicating a shift from an innate to adaptive immune response [146]. A similar study assessing the effects of three weeks of wheel running in $\mathrm{Tg} 2576$ mice begun at 15-19 months showed identical cognitive improvements concomitant with increased expression of the neuroprotection-associated chemokines C-X-C motif ligand 1 (CXCL1) and C-X-C motif 12 (CXCL12) [147]. When 16 month old Tg-NSE/hPS2 mice undergo three months of treadmill running, decreased tau phosphorylation is observed in parallel with decreased expression of cytokines and inflammatory markers and decreased numbers of $\mathrm{GFAP}^{+}$ astrocytes and macrophage 1 antigen (MAC-1) $)^{+}$ microglia [148]. When exercise is begun even later, at 24 months, improved spatial learning in runners is observed coincident with decreased expression of cyclooxygenase-2 (COX2) and caspase- 3 in the cortex and decreased apoptosis in the hippocampus $[149,150]$. Other studies have assessed the possible protective effects of exercise begun before plaque formation or hyperphosphorylation of tau begins. While 12 weeks treadmill running in three month old triple transgenic mice revealed a dose-dependent reduction in chemokine expression in blood and cortex, nine months of voluntary wheel running begun at three months failed to alter the number of $\mathrm{GFAP}^{+}$astrocytes or affect mRNA expression of IL- $1 \beta$, TNF- $\alpha$ and cluster of differentiation 68 (CD68) in the hippocampus of THY-Tau22 mice [151], although tau pathology was reduced and cognitive impairment in the Y-maze task was prevented. The question of how efficacious exercise may be at different phases of the lifespan is key. Independent of AD pathology, age itself is a major risk factor for development of $A D$ and is also associated with inflammation, leading to the coining of the term 'inflammaging'. Age-related increases in inflammatory markers are linked with decreased neurogenesis [152] and cognitive impairment [153], meaning that studies of the effects of exercise on models of AD must consider age as an independent factor. Finally, while most research has focussed on the impact of exercise on cells of the hippocampus and cortex in these models, a recent study showed that voluntary exercise in the triple transgenic mouse model decreased phenotype-associated apoptosis and expression of inflammatory markers in the hypothalamus, suggesting metabolic dysregulation in this model that may be improved by exercise [154]. This is an intriguing result, given evidence of the increased risk of $\mathrm{AD}$ associated with metabolic disorders including type 2 diabetes mellitus [155, 156].

It is evident from these studies and others that crosstalk between the immune and nervous systems allows inflammation to affect neurogenesis and cognition both in wild type and AD mouse models and that exercise provides a potential mechanism to direct and tune the inflammatory response. Few studies to date have examined the effects of exercise on hippocampal neurogenesis, cognitive performance and inflammation in AD models simultaneously; such data could provide new insights into the mechanisms of disease progression and reveal novel therapeutic directions.

\section{CONCLUSION}

A growing body of evidence confirms the pivotal role of inflammation in the genesis and progression of $\mathrm{AD}$ pathology. Our understanding of the profound influence that regular exercise can have on the function of the immune system has grown in parallel. The merging of these bodies of knowledge and their reciprocal influence on the AD field is only beginning. However, we are now beginning to tease out the cellular mechanisms involved in the anti-inflammatory effects of exercise, for example the ability of exercise to modulate macrophage phenotype or 'polarization' in the peripheral tissues. Since exercise can also influence the activation of microglia and astrocytes, cells that play key roles in $\mathrm{AD}$ pathology, the field is ripe for specific assessments of how exercise may influence the phenotype and function of glia in the AD brain. Such studies will provide data leading to refinement of exercise regimes to more effectively regulate the neuroinflammatory response and hence cognitive function in these AD models. As such, it is hoped that a consensus will be reached on the appropriate timing and duration of effective exercise protocols, knowledge that may be of relevance to the human population. In the absence of effective 
pharmaceutical treatment of $\mathrm{AD}$, such information is of even greater importance to the individual and to society.

\section{CONFLICT OF INTEREST}

The author have no conflict of interest to report.

\section{REFERENCES}

[1] Imtiaz B, Tolppanen AM, Kivipelto M, Soininen H. Future directions in Alzheimer's disease from risk factors to prevention. Biochemical Pharmacology. 2014;88(4): 661-70.

[2] Anand A, Patience AA, Sharma N, Khurana N. The present and future of pharmacotherapy of Alzheimer's disease: A comprehensive review. European Journal of Pharmacology. 2017;815:364-75.

[3] Karran E, De Strooper B. The amyloid cascade hypothesis: Are we poised for success or failure? J Neurochem. 2016;139(Suppl 2):237-52.

[4] Reitz C, Mayeux R. Alzheimer disease: Epidemiology, diagnostic criteria, risk factors and biomarkers. Biochemical Pharmacology. 2014;88(4):640-51.

[5] Nicolia V, Lucarelli M, Fuso A. Environment, epigenetics and neurodegeneration: Focus on nutrition in Alzheimer's disease. Experimental Gerontology. 2015;68:8-12.

[6] Stern Y, Gurland B, Tatemichi TK, Tang MX, Wilder $\mathrm{D}$, Mayeux R. Influence of education and occupation on the incidence of Alzheimer's disease. JAMA : The Journal of the American Medical Association. 1994;271(13): 1004-10.

[7] Karp A, Kareholt I, Qiu C, Bellander T, Winblad B, Fratiglioni L. Relation of education and occupation-based socioeconomic status to incident Alzheimer's disease. American Journal of Epidemiology. 2004;159(2):175-83.

[8] Wilson RS, Krueger KR, Arnold SE, Schneider JA, Kelly JF, Barnes LL, et al. Loneliness and risk of Alzheimer disease. Archives of General Psychiatry. 2007;64(2): 234-40.

[9] Rovio S, Kareholt I, Helkala EL, Viitanen M, Winblad $\mathrm{B}$, Tuomilehto J, et al. Leisure-time physical activity at midlife and the risk of dementia and Alzheimer's disease. Lancet Neurology. 2005;4(11):705-11.

[10] Hamer M, Chida Y. Physical activity and risk of neurodegenerative disease: A systematic review of prospective evidence. Psychological Medicine. 2009;39(1):3-11.

[11] Lehnardt S. Innate immunity and neuroinflammation in the CNS: The role of microglia in Toll-like receptor-mediated neuronal injury. Glia. 2010;58(3):253-63.

[12] Bechmann I, Galea I, Perry VH. What is the blood-brain barrier (not)? Trends Immunol. 2007;28(1):5-11.

[13] Colombo E, Farina C. Astrocytes: Key Regulators of Neuroinflammation. Trends Immunol. 2016;37(9):608-20.

[14] Stephenson J, Nutma E, van der Valk P, Amor S. Inflammation in CNS neurodegenerative diseases. Immunology. 2018.

[15] Glezer I, Simard AR, Rivest S. Neuroprotective role of the innate immune system by microglia. Neuroscience. 2007;147(4):867-83.

[16] Scherder E, Scherder R, Verburgh L, Konigs M, Blom M, Kramer AF, et al. Executive functions of sedentary elderly may benefit from walking: A systematic review and metaanalysis. The American Journal of geriatric psychiatry : Official Journal of the American Association for Geriatric Psychiatry. 2014;22(8):782-91.

[17] Falck RS, Davis JC, Liu-Ambrose T. What is the association between sedentary behaviour and cognitive function? A systematic review. British Journal of Sports Medicine. 2017;51(10):800-11.

[18] Middleton LE, Barnes DE, Lui LY, Yaffe K. Physical activity over the life course and its association with cognitive performance and impairment in old age. J Am Geriatr Soc. 2010;58(7):1322-6

[19] Iwasa H, Yoshida Y, Kai I, Suzuki T, Kim H, Yoshida $\mathrm{H}$. Leisure activities and cognitive function in elderly community-dwelling individuals in Japan: A 5-year prospective cohort study. Journal of Psychosomatic Research. 2012;72(2):159-64

[20] Kramer AF, Erickson KI. Effects of physical activity on cognition, well-being, and brain: Human interventions. Alzheimer's \& dementia : The Journal of the Alzheimer's Association. 2007;3(2 Suppl):S45-51.

[21] Larson EB, Wang L, Bowen JD, McCormick WC, Teri $\mathrm{L}$, Crane P, et al. Exercise is associated with reduced risk for incident dementia among persons 65 years of age and older. Annals of Internal Medicine. 2006;144(2): 73-81.

[22] Stephen R, Hongisto K, Solomon A, Lonnroos E. Physical Activity and Alzheimer's Disease: A Systematic Review. The Journals of Gerontology Series A, Biological Sciences and Medical Sciences. 2017;72(6):733-9.

[23] Erickson KI, Prakash RS, Voss MW, Chaddock L, Hu $\mathrm{L}$, Morris KS, et al. Aerobic fitness is associated with hippocampal volume in elderly humans. Hippocampus. 2009;19(10):1030-9.

[24] Barnes JN, Taylor JL, Kluck BN, Johnson CP, Joyner MJ Cerebrovascular reactivity is associated with maximal aerobic capacity in healthy older adults. Journal of Applied Physiology. 2013;114(10):1383-7

[25] Voss MW, Vivar C, Kramer AF, van Praag H. Bridging animal and human models of exercise-induced brain plasticity. Trends in Cognitive Sciences. 2013;17(10): 525-44.

[26] Stern Y. Cognitive reserve. Neuropsychologia. 2009; 47(10):2015-28.

[27] Tucker AM, Stern Y. Cognitive reserve in aging. Current Alzheimer Research. 2011;8(4):354-60.

[28] Arenaza-Urquijo EM, Wirth M, Chetelat G. Cognitive reserve and lifestyle: Moving towards preclinical Alzheimer's disease. Frontiers in Aging Neuroscience. 2015;7:134

[29] Gleeson M, Bishop NC, Stensel DJ, Lindley MR, Mastana SS, Nimmo MA. The anti-inflammatory effects of exercise: Mechanisms and implications for the prevention and treatment of disease. Nat Rev Immunol. 2011;11(9): 607-15.

[30] Ryan SM, Kelly AM. Exercise as a pro-cognitive, pro-neurogenic and anti-inflammatory intervention in transgenic mouse models of Alzheimer's disease. Ageing Research Reviews. 2016;27:77-92.

[31] Mendiola-Precoma J, Berumen LC, Padilla K, GarciaAlcocer G. Therapies for Prevention and Treatment of Alzheimer's Disease. BioMed Research International. 2016;2016:2589276.

[32] Maurer K, Volk S, Gerbaldo H. Auguste D and Alzheimer's disease. Lancet. 1997;349(9064):1546-9. 
[33] Tromp D, Dufour A, Lithfous S, Pebayle T, Despres O. Episodic memory in normal aging and Alzheimer disease: Insights from imaging and behavioral studies. Ageing Research Reviews. 2015;24(Pt B):232-62.

[34] Reisberg B, Franssen EH, Hasan SM, Monteiro I, Boksay I, Souren LE, et al. Retrogenesis: Clinical, physiologic, and pathologic mechanisms in brain aging, Alzheimer's and other dementing processes. European Archives of Psychiatry and Clinical Neuroscience. 1999;249(Suppl 3):28-36

[35] Vickers JC, Dickson TC, Adlard PA, Saunders HL, King $\mathrm{CE}$, McCormack G. The cause of neuronal degeneration in Alzheimer's disease. Progress in Neurobiology. 2000;60(2):139-65.

[36] Crews L, Masliah E. Molecular mechanisms of neurodegeneration in Alzheimer's disease. Human Molecular Genetics. 2010;19(R1):R12-20.

[37] Ingelsson M, Fukumoto H, Newell KL, Growdon JH, Hedley-Whyte ET, Frosch MP, et al. Early Abeta accumulation and progressive synaptic loss, gliosis, and tangle formation in AD brain. Neurology. 2004;62(6): 925-31.

[38] Nelson PT, Braak H, Markesbery WR. Neuropathology and cognitive impairment in Alzheimer disease: A complex but coherent relationship. J Neuropathol Exp Neurol. 2009;68(1):1-14.

[39] Nagele RG, D'Andrea MR, Lee H, Venkataraman V, Wang HY. Astrocytes accumulate A beta 42 and give rise to astrocytic amyloid plaques in Alzheimer disease brains. Brain Res. 2003;971(2):197-209.

[40] Mandrekar-Colucci S, Landreth GE. Microglia and inflammation in Alzheimer's disease. CNS \& Neurological Disorders Drug Targets. 2010;9(2):156-67.

[41] O'Brien RJ, Wong PC. Amyloid precursor protein processing and Alzheimer's disease. Annual Review of Neuroscience. 2011;34:185-204.

[42] Chow VW, Mattson MP, Wong PC, Gleichmann M. An overview of APP processing enzymes and products. Neuromolecular Medicine. 2010;12(1):1-12.

[43] Aizenstein HJ, Nebes RD, Saxton JA, Price JC, Mathis CA, Tsopelas ND, et al. Frequent amyloid deposition without significant cognitive impairment among the elderly. Archives of Neurology. 2008;65(11):1509-17.

[44] Bateman RJ, Xiong C, Benzinger TL, Fagan AM, Goate A, Fox NC, et al. Clinical and biomarker changes in dominantly inherited Alzheimer's disease. The New England Journal of Medicine. 2012;367(9):795-804.

[45] Dai MH, Zheng H, Zeng LD, Zhang Y. The genes associated with early-onset Alzheimer's disease. Oncotarget. 2018;9(19):15132-43.

[46] Burns A, Iliffe S. Alzheimer's disease. Bmj. 2009; 338:b158.

[47] Tiraboschi P, Hansen LA, Masliah E, Alford M, Thal LJ, Corey-Bloom J. Impact of APOE genotype on neuropathologic and neurochemical markers of Alzheimer disease. Neurology. 2004;62(11):1977-83.

[48] Tosto G, Reitz C. Genome-wide association studies in Alzheimer's disease: A review. Current Neurology and Neuroscience Reports. 2013;13(10):381.

[49] Tosto G, Reitz C. Genomics of Alzheimer's disease: Value of high-throughput genomic technologies to dissect its etiology. Mol Cell Probes. 2016;30(6):397-403

[50] Wisniewski T, Sigurdsson EM. Murine models of Alzheimer's disease and their use in developing immunotherapies. Biochim Biophys Acta. 2010;1802(10):84759.
[51] Pozueta J, Lefort R, Shelanski ML. Synaptic changes in Alzheimer's disease and its models. Neuroscience. 2013;251:51-65.

[52] Ameen-Ali KE, Wharton SB, Simpson JE, Heath PR, Sharp P, Berwick J. Review: Neuropathology and behavioural features of transgenic murine models of Alzheimer's disease. Neuropathology and Applied Neurobiology. 2017;43(7):553-70.

[53] Jankowsky JL, Zheng H. Practical considerations for choosing a mouse model of Alzheimer's disease. Molecular Neurodegeneration. 2017;12(1):89.

[54] Hsiao K, Chapman P, Nilsen S, Eckman C, Harigaya Y, Younkin S, et al. Correlative memory deficits, Abeta elevation, and amyloid plaques in transgenic mice. Science. 1996;274(5284):99-102.

[55] Games D, Adams D, Alessandrini R, Barbour R, Berthelette P, Blackwell C, et al. Alzheimer-type neuropathology in transgenic mice overexpressing V717F beta-amyloid precursor protein. Nature. 1995;373(6514):523-7.

[56] Masliah E, Sisk A, Mallory M, Games D. Neurofibrillary pathology in transgenic mice overexpressing V717F beta-amyloid precursor protein. J Neuropathol Exp Neurol. 2001;60(4):357-68.

[57] Duff K, Eckman C, Zehr C, Yu X, Prada CM, Pereztur $\mathrm{J}$, et al. Increased amyloid-beta42(43) in brains of mice expressing mutant presenilin 1. Nature. 1996; 383(6602):710-3.

[58] Holcomb L, Gordon MN, McGowan E, Yu X, Benkovic S, Jantzen P, et al. Accelerated Alzheimer-type phenotype in transgenic mice carrying both mutant amyloid precursor protein and presenilin 1 transgenes. Nature Medicine. 1998;4(1):97-100.

[59] Jankowsky JL, Fadale DJ, Anderson J, Xu GM, Gonzales $\mathrm{V}$, Jenkins NA, et al. Mutant presenilins specifically elevate the levels of the 42 residue beta-amyloid peptide in vivo: Evidence for augmentation of a 42-specific gamma secretase. Human Molecular Genetics. 2004;13(2): 159-70.

[60] Lee HJ, Lee JK, Lee H, Carter JE, Chang JW, Oh W, et al. Human umbilical cord blood-derived mesenchymal stem cells improve neuropathology and cognitive impairment in an Alzheimer's disease mouse model through modulation of neuroinflammation. Neurobiol Aging. 2012;33(3):588602.

[61] Ramos-Rodriguez JJ, Molina-Gil S, Rey-Brea R, Berrocoso E, Garcia-Alloza M. Specific serotonergic denervation affects tau pathology and cognition without altering senile plaques deposition in APP/PS1 mice. PLoS One. 2013;8(11):e79947.

[62] Soto I, Grabowska WA, Onos KD, Graham LC, Jackson HM, Simeone SN, et al. Meox2 haploinsufficiency increases neuronal cell loss in a mouse model of Alzheimer's disease. Neurobiol Aging. 2016;42: 50-60.

[63] Oddo S, Caccamo A, Shepherd JD, Murphy MP, Golde TE, Kayed R, et al. Triple-transgenic model of Alzheimer's disease with plaques and tangles: Intracellular Abeta and synaptic dysfunction. Neuron. 2003;39(3):409-21.

[64] Oddo S, LaFerla FM. The role of nicotinic acetylcholine receptors in Alzheimer's disease. J Physiol Paris. 2006;99(2-3):172-9.

[65] Watamura N, Toba J, Yoshii A, Nikkuni M, Ohshima T. Colocalization of phosphorylated forms of WAVE1, CRMP2, and tau in Alzheimer's disease model mice: Involvement of $\mathrm{Cdk} 5$ phosphorylation and the effect 
of ATRA treatment. Journal of Neuroscience Research. 2016;94(1):15-26.

[66] Kang S, Moon NR, Kim DS, Kim SH, Park S. Central acylated ghrelin improves memory function and hippocampal AMPK activation and partly reverses the impairment of energy and glucose metabolism in rats infused with betaamyloid. Peptides. 2015;71:84-93.

[67] Frautschy SA, Yang F, Calderon L, Cole GM. Rodent models of Alzheimer's disease: Rat A beta infusion approaches to amyloid deposits. Neurobiol Aging. 1996;17(2): 311-21.

[68] Stephan A, Laroche S, Davis S. Learning deficits and dysfunctional synaptic plasticity induced by aggregated amyloid deposits in the dentate gyrus are rescued by chronic treatment with indomethacin. Eur J Neurosci. 2003;17(9):1921-7.

[69] Webster SJ, Bachstetter AD, Nelson PT, Schmitt FA, Van Eldik LJ. Using mice to model Alzheimer's dementia: An overview of the clinical disease and the preclinical behavioral changes in 10 mouse models. Front Genet. 2014;5:88.

[70] Hartman RE, Izumi Y, Bales KR, Paul SM, Wozniak DF, Holtzman DM. Treatment with an amyloid-beta antibody ameliorates plaque load, learning deficits, and hippocampal long-term potentiation in a mouse model of Alzheimer's disease. J Neurosci. 2005;25(26):6213-20.

[71] Westerman MA, Cooper-Blacketer D, Mariash A, Kotilinek L, Kawarabayashi T, Younkin LH, et al. The relationship between Abeta and memory in the Tg2576 mouse model of Alzheimer's disease. J Neurosci. 2002;22(5):1858-67.

[72] Oules B, Del Prete D, Greco B, Zhang X, Lauritzen I, Sevalle J, et al. Ryanodine receptor blockade reduces amyloid-beta load and memory impairments in Tg2576 mouse model of Alzheimer disease. J Neurosci. 2012;32(34):11820-34.

[73] Holcomb LA, Gordon MN, Jantzen P, Hsiao K, Duff $\mathrm{K}$, Morgan D. Behavioral changes in transgenic mice expressing both amyloid precursor protein and presenilin1 mutations: Lack of association with amyloid deposits. Behavior Genetics. 1999;29(3):177-85.

[74] Trinchese F, Liu S, Battaglia F, Walter S, Mathews $\mathrm{PM}$, Arancio O. Progressive age-related development of Alzheimer-like pathology in APP/PS1 mice. Annals of Neurology. 2004;55(6):801-14.

[75] Jardanhazi-Kurutz D, Kummer MP, Terwel D, Vogel $\mathrm{K}$, Dyrks T, Thiele A, et al. Induced LC degeneration in APP/PS1 transgenic mice accelerates early cerebral amyloidosis and cognitive deficits. Neurochemistry International. 2010;57(4):375-82.

[76] Billings LM, Oddo S, Green KN, McGaugh JL, LaFerla FM. Intraneuronal Abeta causes the onset of early Alzheimer's disease-related cognitive deficits in transgenic mice. Neuron. 2005;45(5):675-88.

[77] Clinton LK, Billings LM, Green KN, Caccamo A, Ngo $\mathrm{J}$, Oddo S, et al. Age-dependent sexual dimorphism in cognition and stress response in the $3 \times \mathrm{Tg}-\mathrm{AD}$ mice. Neurobiology of Disease. 2007;28(1):76-82.

[78] Pietropaolo S, Feldon J, Yee BK. Age-dependent phenotypic characteristics of a triple transgenic mouse model of Alzheimer disease. Behav Neurosci. 2008;122(4):733-47.

[79] Heneka MT. Inflammasome activation and innate immunity in Alzheimer's disease. Brain pathology. 2017;27(2):220-2.

[80] Heneka MT, Kummer MP, Stutz A, Delekate A, Schwartz $\mathrm{S}$, Vieira-Saecker A, et al. NLRP3 is activated in
Alzheimer's disease and contributes to pathology in APP/PS1 mice. Nature. 2013;493(7434):674-8.

[81] Heppner FL, Ransohoff RM, Becher B. Immune attack: The role of inflammation in Alzheimer disease. Nature reviews Neuroscience. 2015;16(6):358-72.

[82] Shadfar S, Hwang CJ, Lim MS, Choi DY, Hong JT. Involvement of inflammation in Alzheimer's disease pathogenesis and therapeutic potential of antiinflammatory agents. Archives of Pharmacal Research. 2015.

[83] McGeer PL, McGeer EG. The amyloid cascadeinflammatory hypothesis of Alzheimer disease: Implications for therapy. Acta Neuropathologica. 2013;126(4):479-97.

[84] Sastre M, Klockgether T, Heneka MT. Contribution of inflammatory processes to Alzheimer's disease: Molecular mechanisms. Int J Dev Neurosci. 2006;24(2-3):167-76.

[85] Cacabelos R, Alvarez XA, Fernandez-Novoa L, Franco A, Mangues R, Pellicer A, et al. Brain interleukin-1 beta in Alzheimer's disease and vascular dementia. Methods Find Exp Clin Pharmacol. 1994;16(2):141-51.

[86] Tarkowski E, Andreasen N, Tarkowski A, Blennow $\mathrm{K}$. Intrathecal inflammation precedes development of Alzheimer's disease. J Neurol Neurosurg Psychiatry. 2003;74(9):1200-5.

[87] Yokoyama JS, Wang Y, Schork AJ, Thompson WK, Karch $\mathrm{CM}$, Cruchaga C, et al. Association Between Genetic Traits for Immune-Mediated Diseases and Alzheimer Disease. JAMA Neurol. 2016;73(6):691-7.

[88] Deardorff WJ, Grossberg GT. Targeting neuroinflammation in Alzheimer's disease: Evidence for NSAIDs and novel therapeutics. Expert Rev Neurother. 2017;17(1): 17-32.

[89] Minter MR, Taylor JM, Crack PJ. The contribution of neuroinflammation to amyloid toxicity in Alzheimer's disease. J Neurochem. 2016;136(3):457-74.

[90] Pekny M, Pekna M. Astrocyte reactivity and reactive astrogliosis: Costs and benefits. Physiol Rev. 2014;94(4):1077-98.

[91] McManus RM, Finucane OM, Wilk MM, Mills KHG, Lynch MA. FTY720 Attenuates Infection-Induced Enhancement of Abeta Accumulation in APP/PS1 Mice by Modulating Astrocytic Activation. Journal of neuroimmune pharmacology : The official journal of the Society on NeuroImmune Pharmacology. 2017;12(4): 670-81.

[92] Duffy AM, Holscher C. The incretin analogue D-Ala2GIP reduces plaque load, astrogliosis and oxidative stress in an APP/PS1 mouse model of Alzheimer's disease. Neuroscience. 2013;228:294-300.

[93] Balasingam V, Tejada-Berges T, Wright E, Bouckova R, Yong VW. Reactive astrogliosis in the neonatal mouse brain and its modulation by cytokines. J Neurosci. 1994;14(2):846-56.

[94] Hatfield JS, Skoff RP. GFAP immunoreactivity reveals astrogliosis in females heterozygous for jimpy. Brain Res. 1982;250(1):123-31.

[95] Kamphuis W, Middeldorp J, Kooijman L, Sluijs JA, Kooi EJ, Moeton M, et al. Glial fibrillary acidic protein isoform expression in plaque related astrogliosis in Alzheimer's disease. Neurobiol Aging. 2014;35(3):492-510.

[96] Nagele RG, Wegiel J, Venkataraman V, Imaki H, Wang $\mathrm{KC}$, Wegiel J. Contribution of glial cells to the development of amyloid plaques in Alzheimer's disease. Neurobiol Aging. 2004;25(5):663-74. 
[97] Gonzalez-Reyes RE, Nava-Mesa MO, Vargas-Sanchez $\mathrm{K}$, Ariza-Salamanca D, Mora-Munoz L. Involvement of Astrocytes in Alzheimer's Disease from a Neuroinflammatory and Oxidative Stress Perspective. Frontiers in Molecular Neuroscience. 2017;10:427.

[98] Kraft AW, Hu X, Yoon H, Yan P, Xiao Q, Wang Y, et al. Attenuating astrocyte activation accelerates plaque pathogenesis in APP/PS1 mice. FASEB journal : Official Publication of the Federation of American Societies for Experimental Biology. 2013;27(1):187-98.

[99] Schwab C, Klegeris A, McGeer PL. Inflammation in transgenic mouse models of neurodegenerative disorders. Biochim Biophys Acta. 2010;1802(10):889-902.

[100] Hansen DV, Hanson JE, Sheng M. Microglia in Alzheimer's disease. The Journal of Cell Biology. 2018;217(2):459-72.

[101] ElAli A, Rivest S. Microglia in Alzheimer's disease: A multifaceted relationship. Brain, Behavior, and Immunity. 2016;55:138-50.

[102] Johansson JU, Woodling NS, Wang Q, Panchal M, Liang $\mathrm{X}$, Trueba-Saiz A, et al. Prostaglandin signaling suppresses beneficial microglial function in Alzheimer's disease models. The Journal of Clinical Investigation. 2015;125(1):350-64.

[103] Minogue AM, Jones RS, Kelly RJ, McDonald CL, Connor TJ, Lynch MA. Age-associated dysregulation of microglial activation is coupled with enhanced bloodbrain barrier permeability and pathology in APP/PS1 mice. Neurobiol Aging. 2014;35(6):1442-52.

[104] Hickman SE, Allison EK, El Khoury J. Microglial dysfunction and defective beta-amyloid clearance pathways in aging Alzheimer's disease mice. J Neurosci. 2008;28(33):8354-60.

[105] Meyer-Luehmann M, Spires-Jones TL, Prada C, GarciaAlloza M, de Calignon A, Rozkalne A, et al. Rapid appearance and local toxicity of amyloid-beta plaques in a mouse model of Alzheimer's disease. Nature. 2008;451(7179):720-4.

[106] Boissonneault V, Filali M, Lessard M, Relton J, Wong $\mathrm{G}$, Rivest S. Powerful beneficial effects of macrophage colony-stimulating factor on beta-amyloid deposition and cognitive impairment in Alzheimer's disease. Brain : A Journal of Neurology. 2009;132(Pt 4):1078-92.

[107] Kiyota T, Okuyama S, Swan RJ, Jacobsen MT, Gendelman HE, Ikezu T. CNS expression of anti-inflammatory cytokine interleukin-4 attenuates Alzheimer's diseaselike pathogenesis in APP+PS1 bigenic mice. FASEB journal : Official publication of the Federation of American Societies for Experimental Biology. 2010;24(8): 3093-102.

[108] Bachstetter AD, Norris CM, Sompol P, Wilcock DM, Goulding D, Neltner $\mathrm{JH}$, et al. Early stage drug treatment that normalizes proinflammatory cytokine production attenuates synaptic dysfunction in a mouse model that exhibits age-dependent progression of Alzheimer's disease-related pathology. J Neurosci. 2012;32(30):10201-10.

[109] Streit WJ, Xue QS. Human CNS immune senescence and neurodegeneration. Curr Opin Immunol. 2014;29:93-6.

[110] Beavers KM, Brinkley TE, Nicklas BJ. Effect of exercise training on chronic inflammation. Clinica Chimica Acta; International Journal of Clinical Chemistry. 2010;411(1112):785-93.

[111] Febbraio MA, Pedersen BK. Muscle-derived interleukin6: Mechanisms for activation and possible biological roles. FASEB journal : Official publication of the Federation of American Societies for Experimental Biology. 2002;16(11):1335-47.

[112] Ostrowski K, Hermann C, Bangash A, Schjerling P, Nielsen JN, Pedersen BK. A trauma-like elevation of plasma cytokines in humans in response to treadmill running. The Journal of Physiology. 1998;513(Pt 3):889-94.

[113] Ostrowski K, Rohde T, Asp S, Schjerling P, Pedersen BK. Pro- and anti-inflammatory cytokine balance in strenuous exercise in humans. The Journal of Physiology. 1999;515(Pt 1):287-91

[114] Spielman LJ, Little JP, Klegeris A. Physical activity and exercise attenuate neuroinflammation in neurological diseases. Brain Research Bulletin. 2016;125:19-29.

[115] McFarlin BK, Flynn MG, Campbell WW, Craig BA, Robinson JP, Stewart LK, et al. Physical activity status, but not age, influences inflammatory biomarkers and toll-like receptor 4. The Journals of Gerontology Series A, Biological Sciences and Medical Sciences. 2006;61(4):388-93.

[116] Gomes da Silva S, Simoes PS, Mortara RA, Scorza FA, Cavalheiro EA, da Graca Naffah-Mazzacoratti M, et al. Exercise-induced hippocampal anti-inflammatory response in aged rats. Journal of Neuroinflammation. 2013;10:61

[117] Littlefield AM, Setti SE, Priester C, Kohman RA. Voluntary exercise attenuates LPS-induced reductions in neurogenesis and increases microglia expression of a proneurogenic phenotype in aged mice. Journal of Neuroinflammation. 2015;12:138

[118] He XF, Liu DX, Zhang Q, Liang FY, Dai GY, Zeng JS, et al. Voluntary Exercise Promotes Glymphatic Clearance of Amyloid Beta and Reduces the Activation of Astrocytes and Microglia in Aged Mice. Frontiers in Molecular Neuroscience. 2017;10:144.

[119] Kempermann G, Gage FH, Aigner L, Song H, Curtis MA, Thuret S, et al. Human Adult Neurogenesis: Evidence and Remaining Questions. Cell Stem Cell. 2018.

[120] Eriksson PS, Perfilieva E, Bjork-Eriksson T, Alborn AM, Nordborg C, Peterson DA, et al. Neurogenesis in the adult human hippocampus. Nature Medicine. 1998;4(11): 1313-7.

[121] Spalding KL, Bergmann O, Alkass K, Bernard S, Salehpour M, Huttner HB, et al. Dynamics of hippocampal neurogenesis in adult humans. Cell. 2013;153(6):1219-27.

[122] Boldrini M, Fulmore CA, Tartt AN, Simeon LR, Pavlova I, Poposka V, et al. Human Hippocampal Neurogenesis Persists throughout Aging. Cell Stem Cell. 2018;22(4):589-99 e5.

[123] Sorrells SF, Paredes MF, Cebrian-Silla A, Sandoval K, Qi D, Kelley KW, et al. Human hippocampal neurogenesis drops sharply in children to undetectable levels in adults. Nature. 2018;555(7696):377-81.

[124] van Praag H, Christie BR, Sejnowski TJ, Gage FH Running enhances neurogenesis, learning, and longterm potentiation in mice. Proc Natl Acad Sci U S A 1999;96(23):13427-31.

[125] van Praag H, Shubert T, Zhao C, Gage FH. Exercise enhances learning and hippocampal neurogenesis in aged mice. J Neurosci. 2005;25(38):8680-5.

[126] Ekdahl CT, Claasen JH, Bonde S, Kokaia Z, Lindvall O. Inflammation is detrimental for neurogenesis in adult brain. Proc Natl Acad Sci U S A. 2003;100(23):13632-7.

[127] Monje ML, Toda H, Palmer TD. Inflammatory blockade restores adult hippocampal neurogenesis. Science (New York, NY). 2003;302(5651):1760-5. 
[128] Koo JW, Duman RS. IL-1beta is an essential mediator of the antineurogenic and anhedonic effects of stress. Proc Natl Acad Sci U S A. 2008;105(2):751-6.

[129] Borsini A, Alboni S, Horowitz MA, Tojo LM, Cannazza $\mathrm{G}, \mathrm{Su} \mathrm{KP}$, et al. Rescue of IL-1beta-induced reduction of human neurogenesis by omega-3 fatty acids and antidepressants. Brain, Behavior, and Immunity. 2017;65: 230-8.

[130] O'Leime CS, Kozareva DA, Hoban AE, Long-Smith CM, Cryan JF, Nolan YM. TLX is an intrinsic regulator of the negative effects of IL-1beta on proliferating hippocampal neural progenitor cells. FASEB journal : Official Publication of the Federation of American Societies for Experimental Biology. 2018;32(2):613-24.

[131] Jiang L, Ma J, Zhang Y, Zhou CN, Zhang L, Chao FL, et al. Effect of running exercise on the number of the neurons in the hippocampus of young transgenic APP/PS1 mice. Brain Res. 2018.

[132] Zhao G, Liu HL, Zhang H, Tong XJ. Treadmill exercise enhances synaptic plasticity, but does not alter betaamyloid deposition in hippocampi of aged APP/PS1 transgenic mice. Neuroscience. 2015;298:357-66.

[133] Lin TW, Shih YH, Chen SJ, Lien CH, Chang CY, Huang TY, et al. Running exercise delays neurodegeneration in amygdala and hippocampus of Alzheimer's disease (APP/PS1) transgenic mice. Neurobiol Learn Mem. 2015;118:189-97.

[134] Bo H, Kang W, Jiang N, Wang X, Zhang Y, Ji LL. Exerciseinduced neuroprotection of hippocampus in APP/PS1 transgenic mice via upregulation of mitochondrial 8oxoguanine DNA glycosylase. Oxidative Medicine and Cellular Longevity. 2014;2014:834502.

[135] Moore KM, Girens RE, Larson SK, Jones MR, Restivo JL, Holtzman DM, et al. A spectrum of exercise training reduces soluble Abeta in a dose-dependent manner in a mouse model of Alzheimer's disease. Neurobiology of Disease. 2016;85:218-24

[136] Yuede CM, Zimmerman SD, Dong H, Kling MJ, Bero AW, Holtzman DM, et al. Effects of voluntary and forced exercise on plaque deposition, hippocampal volume, and behavior in the $\operatorname{Tg} 2576$ mouse model of Alzheimer's disease. Neurobiology of Disease. 2009;35(3):426-32.

[137] Cho JY, Hwang DY, Kang TS, Shin DH, Hwang JH, Lim $\mathrm{CH}$, et al. Use of NSE/PS2m-transgenic mice in the study of the protective effect of exercise on Alzheimer's disease. Journal of Sports Sciences. 2003;21(11):943-51.

[138] Cho J, Shin MK, Kim D, Lee I, Kim S, Kang H. Treadmill Running Reverses Cognitive Declines due to Alzheimer Disease. Medicine and Science in Sports and Exercise. 2015;47(9):1814-24.

[139] Revilla S, Sunol C, Garcia-Mesa Y, Gimenez-Llort L, Sanfeliu C, Cristofol R. Physical exercise improves synaptic dysfunction and recovers the loss of survival factors in 3xTg-AD mouse brain. Neuropharmacology. 2014;81:5563.

[140] Huttenrauch M, Brauss A, Kurdakova A, Borgers H, Klinker F, Liebetanz D, et al. Physical activity delays hippocampal neurodegeneration and rescues memory deficits in an Alzheimer disease mouse model. Translational Psychiatry. 2016;6:e800.

[141] Tapia-Rojas C, Aranguiz F, Varela-Nallar L, Inestrosa NC. Voluntary Running Attenuates Memory Loss, Decreases Neuropathological Changes and Induces Neurogenesis in a Mouse Model of Alzheimer's Disease. Brain Pathology. 2015
[142] Zhang J, Guo Y, Wang Y, Song L, Zhang R, Du Y. Long-term treadmill exercise attenuates Abeta burdens and astrocyte activation in APP/PS1 mouse model of Alzheimer's disease. Neuroscience letters. 2018;666:70-7.

[143] Ke HC, Huang HJ, Liang KC, Hsieh-Li HM. Selective improvement of cognitive function in adult and aged APP/PS1 transgenic mice by continuous non-shock treadmill exercise. Brain Res. 2011;1403:1-11.

[144] Xu ZQ, Zhang LQ, Wang Q, Marshall C, Xiao N, Gao JY, et al. Aerobic exercise combined with antioxidative treatment does not counteract moderate- or mid-stage Alzheimer-like pathophysiology of APP/PS1 mice. CNS Neuroscience \& Therapeutics. 2013;19(10):795-803.

[145] Nichol KE, Parachikova AI, Cotman CW. Three weeks of running wheel exposure improves cognitive performance in the aged Tg2576 mouse. Behav Brain Res. 2007;184(2):124-32.

[146] Nichol KE, Poon WW, Parachikova AI, Cribbs DH, Glabe CG, Cotman CW. Exercise alters the immune profile in $\operatorname{Tg} 2576$ Alzheimer mice toward a response coincident with improved cognitive performance and decreased amyloid. Journal of Neuroinflammation. 2008;5:13.

[147] Parachikova A, Nichol KE, Cotman CW. Short-term exercise in aged $\operatorname{Tg} 2576$ mice alters neuroinflammation and improves cognition. Neurobiology of Disease. 2008;30(1):121-9.

[148] Leem YH, Lee YI, Son HJ, Lee SH. Chronic exercise ameliorates the neuroinflammation in mice carrying NSE/htau23. Biochemical and Biophysical Research Communications. 2011;406(3):359-65.

[149] Koo JH, Kwon IS, Kang EB, Lee CK, Lee NH, Kwon MG, et al. Neuroprotective effects of treadmill exercise on BDNF and PI3-K/Akt signaling pathway in the cortex of transgenic mice model of Alzheimer's disease. Journal of Exercise Nutrition \& Biochemistry. 2013;17(4): 151-60.

[150] Um HS, Kang EB, Koo JH, Kim HT, Jin L, Kim EJ, et al. Treadmill exercise represses neuronal cell death in an aged transgenic mouse model of Alzheimer's disease. Neuroscience Research. 2011;69(2):161-73.

[151] Belarbi K, Burnouf S, Fernandez-Gomez FJ, Laurent C, Lestavel S, Figeac M, et al. Beneficial effects of exercise in a transgenic mouse model of Alzheimer's diseaselike Tau pathology. Neurobiology of Disease. 2011;43(2): 486-94.

[152] Boehme M, Guenther M, Stahr A, Liebmann M, Jaenisch $\mathrm{N}$, Witte OW, et al. Impact of indomethacin on neuroinflammation and hippocampal neurogenesis in aged mice. Neuroscience Letters. 2014;572:7-12.

[153] d'Avila JC, Siqueira LD, Mazeraud A, Azevedo EP, Foguel $\mathrm{D}$, Castro-Faria-Neto HC, et al. Age-related cognitive impairment is associated with long-term neuroinflammation and oxidative stress in a mouse model of episodic systemic inflammation. Journal of Neuroinflammation. 2018;15(1):28.

[154] Do K, Laing BT, Landry T, Bunner W, Mersaud N, Matsubara $\mathrm{T}$, et al. The effects of exercise on hypothalamic neurodegeneration of Alzheimer's disease mouse model. PLoS One. 2018;13(1):e0190205.

[155] Cheng D, Noble J, Tang MX, Schupf N, Mayeux R, Luchsinger JA. Type 2 diabetes and late-onset Alzheimer's disease. Dementia and Geriatric Cognitive Disorders. 2011;31(6):424-30.

[156] Profenno LA, Porsteinsson AP, Faraone SV. Metaanalysis of Alzheimer's disease risk with obesity, diabetes, 
and related disorders. Biological Psychiatry. 2010;67(6): 505-12.

[157] Derecki NC, Kipnis J. From neurons to microglia, with complements. Nature Neuroscience. 2013;16(12):1712-3.

[158] Ransohoff RM, Cardona AE. The myeloid cells of the central nervous system parenchyma. Nature. 2010;468(7321):253-62.

[159] Sunnemark D, Eltayeb S, Nilsson M, Wallstrom E, Lassmann $\mathrm{H}$, Olsson $\mathrm{T}$, et al. CX3CL1 (fractalkine) and CX3CR1 expression in myelin oligodendrocyte glycoprotein-induced experimental autoimmune encephalomyelitis: Kinetics and cellular origin. Journal of Neuroinflammation. 2005;2:17.

[160] Lyons A, Downer EJ, Crotty S, Nolan YM, Mills KH, Lynch MA. CD200 ligand receptor interaction modulates microglial activation in vivo and in vitro: A role for IL-4. J Neurosci. 2007;27(31):8309-13.

[161] Ferreira R, Bernardino L. Dual role of microglia in health and disease: Pushing the balance toward repair. Frontiers in Cellular Neuroscience. 2015;9:51.

[162] Cherry JD, Olschowka JA, O'Banion MK. Neuroinflammation and M2 microglia: The good, the bad, and the inflamed. Journal of Neuroinflammation. 2014;11:98.

[163] Orihuela R, McPherson CA, Harry GJ. Microglial M1/M2 polarization and metabolic states. $\mathrm{Br} \mathrm{J}$ Pharmacol. 2016;173(4):649-65.

[164] Hu X, Liou AK, Leak RK, Xu M, An C, Suenaga J, et al. Neurobiology of microglial action in CNS injuries: Receptor-Mediated signaling mechanisms and functional roles. Progress in Neurobiology. 2014;119-120:60-84.

[165] Ryu KY, Cho GS, Piao HZ, Kim WK. Role of TGF-beta in Survival of Phagocytizing Microglia: Autocrine Suppression of TNF-alpha Production and Oxidative Stress. Experimental neurobiology. 2012;21(4):151-7.

[166] Gomes C, Ferreira R, George J, Sanches R, Rodrigues DI, Goncalves N, et al. Activation of microglial cells triggers a release of brain-derived neurotrophic factor (BDNF) inducing their proliferation in an adenosine A2A receptor-dependent manner: A2A receptor blockade prevents BDNF release and proliferation of microglia. Journal of Neuroinflammation. 2013;10:16.

[167] Nakagawa Y, Chiba K. Diversity and plasticity of microglial cells in psychiatric and neurological disorders. Pharmacology \& Therapeutics. 2015;154:21-35.

[168] Tang Y, Le W. Differential Roles of M1 and M2 Microglia in Neurodegenerative Diseases. Molecular Neurobiology. 2016;53(2):1181-94.

[169] Amici SA, Dong J, Guerau-de-Arellano M. Molecular Mechanisms Modulating the Phenotype of Macrophages and Microglia. Front Immunol. 2017;8:1520.

[170] Ransohoff RM. A polarizing question: Do M1 and M2 microglia exist? Nature Neuroscience. 2016;19(8):98791.

[171] Hu X, Leak RK, Shi Y, Suenaga J, Gao Y, Zheng $\mathrm{P}$, et al. Microglial and macrophage polarization-new prospects for brain repair. Nature reviews Neurology. 2015;11(1):56-64.

[172] Perea G, Navarrete M, Araque A. Tripartite synapses: Astrocytes process and control synaptic information. Trends in Neurosciences. 2009;32(8):421-31.

[173] Liu B, Teschemacher AG, Kasparov S. Astroglia as a cellular target for neuroprotection and treatment of neuropsychiatric disorders. Glia. 2017;65(8):1205-26.
[174] Sofroniew MV, Vinters HV. Astrocytes: Biology and pathology. Acta Neuropathologica. 2010;119(1):7-35.

[175] Anderson MA, Ao Y, Sofroniew MV. Heterogeneity of reactive astrocytes. Neuroscience Letters. 2014;565:23-9.

[176] Jang E, Kim JH, Lee S, Kim JH, Seo JW, Jin M, et al. Phenotypic polarization of activated astrocytes: The critical role of lipocalin-2 in the classical inflammatory activation of astrocytes. J Immunol. 2013;191(10):5204-19.

[177] Rothhammer V, Quintana FJ. Control of autoimmune CNS inflammation by astrocytes. Semin Immunopathol. 2015;37(6):625-38.

[178] Liddelow SA, Barres BA. Reactive Astrocytes: Production, Function, and Therapeutic Potential. Immunity. 2017;46(6):957-67.

[179] He ML, Lv ZY, Shi X, Yang T, Zhang Y, Li TY, et al. Interleukin-10 release from astrocytes suppresses neuronal apoptosis via the TLR2/NFkappaB pathway in a neonatal rat model of hypoxic-ischemic brain damage. $\mathrm{J}$ Neurochem. 2017.

[180] Bradford J, Shin JY, Roberts M, Wang CE, Li XJ, Li S. Expression of mutant huntingtin in mouse brain astrocytes causes age-dependent neurological symptoms. Proc Natl Acad Sci U S A. 2009;106(52):22480-5.

[181] Allaman I, Gavillet M, Belanger M, Laroche T, Viertl D, Lashuel HA, et al. Amyloid-beta aggregates cause alterations of astrocytic metabolic phenotype: Impact on neuronal viability. J Neurosci. 2010;30(9):3326-38.

[182] Halliday GM, Stevens CH. Glia: Initiators and progressors of pathology in Parkinson's disease. Movement disorders : Official journal of the Movement Disorder Society. 2011;26(1):6-17.

[183] Clarke LE, Liddelow SA, Chakraborty C, Munch AE, Heiman M, Barres BA. Normal aging induces A1like astrocyte reactivity. Proc Natl Acad Sci U S A. 2018;115(8):E1896-E905.

[184] Liddelow SA, Guttenplan KA, Clarke LE, Bennett FC, Bohlen CJ, Schirmer L, et al. Neurotoxic reactive astrocytes are induced by activated microglia. Nature. 2017;541(7638):481-7.

[185] Borchelt DR, Ratovitski T, van Lare J, Lee MK, Gonzales $\mathrm{V}$, Jenkins NA, et al. Accelerated amyloid deposition in the brains of transgenic mice coexpressing mutant presenilin 1 and amyloid precursor proteins. Neuron. 1997;19(4):93945 .

[186] Hwang DY, Chae KR, Kang TS, Hwang JH, Lim CH, Kang HK, et al. Alterations in behavior, amyloid beta42, caspase- 3 , and Cox-2 in mutant PS2 transgenic mouse model of Alzheimer's disease. FASEB journal : Official publication of the Federation of American Societies for Experimental Biology. 2002;16(8):805-13.

[187] Haskins M, Jones TE, Lu Q, Bareiss SK. Early alterations in blood and brain RANTES and MCP-1 expression and the effect of exercise frequency in the $3 \times \mathrm{Tg}-\mathrm{AD}$ mouse model of Alzheimer's disease. Neuroscience letters. 2016;610:165-70.

[188] Schindowski K, Bretteville A, Leroy K, Begard S, Brion JP, Hamdane M, et al. Alzheimer's disease-like tau neuropathology leads to memory deficits and loss of functional synapses in a novel mutated tau transgenic mouse without any motor deficits. The American Journal of Pathology. 2006;169(2):599-616. 